\title{
TOXICITY TEST DIETHYL ETHER EKSTRACT Oxalis corniculata L. HERB ON BRINE SHRIMP LETHALITY TEST METHOD
}

\author{
Herwin, Rachmat Kosman, Muzakkir Baits \\ Fakultas Farmasi Universitas Muslim Indonesia \\ Email : herwinfarmasi@gmail.com
}

\begin{abstract}
Recearch toxicity effect of standar dietil eter ekstract Oxalis corniculata $L$. herb at Artemia salina Leach with purpose to determine toxicity potencial and $L C_{50}$ value Oxalis corniculata $L$. herb on brine shrimp lethality test method. The result of this research shows that diethyl ether ekstract Oxalis corniculata L. herb at concentration 100, 50, 5, 1, 0.5, 0.1,0.05, $0.01 \mu \mathrm{g} / \mathrm{ml}$ and controler is diethyl ether. Presentation data of Artemia salina Leach larvae was analyzed with probit analysis to count $L C_{50}$. Ekstract is toxic if $L C 50$ value $<1000 \mu \mathrm{g} / \mathrm{ml}$. So obtained that diethyl ether ekstrak Oxalis corniculata L. herb is toxit to Artemia salina Leach larvae with $L C_{50} 4,17 \pm 2,59 \mu \mathrm{g} / \mathrm{ml}$.
\end{abstract}

Key words : Oxalis corniculata L, Toxicity, Brine Shrimp Lethality Test.

\section{PENDAHULUAN}

Keanekaragaman hayati yang ada di bumi ini tak hanya digunakan sebagai bahan pangan atau hiasan, tetapi juga bermanfaat sebagai bahan untuk mengobati berbagai penyakit. Tanaman yang ada, terutama yang tumbuh di Indonesia dikenal sebagai bahan yang ampuh sebagai obat dan digunakan sebagai bahan obat tradisional.

Belakangan ini telah banyak dilakukan penelitian mengenai tanaman yang berpotensi sebagai obat tradisional. Salah satu tanaman tradisional yang diteliti adalah belimbing tanah (Oxalis corniculata L.).
Herba belimbing tanah (Oxalis corniculata L.) merupakan tumbuhan yang digunakan sebagai obat tradisional oleh masyarakat Mamuju Sulawesi barat yaitu obat flu dan batuk. Secara empiris herba belimbing tanah (Oxalis corniculata L.) digunakan untuk mengatasi demam, flu, diare, radang hati (hepatitis), radang tenggorokan, infeksi saluran kencing, terlambat haid, hipertensi dan neurasthenia (kelemahan badan). Dan dilaporkan mengandung karbohidrat, glikosida, phytosterol, asam oksalat, saponin, flavonoida, polifenol, asam amino, protein $12,5 \%$, volatile oil dan tanin. Selain itu ia juga kaya 
Toxicity Test Diethyl Ether Ekstract Oxalis corniculata L. Herb On Brine Shrimp Lethality Test Method

dengan vitamin $\mathrm{B}$, zat besi dan kalsium. Daunnya pula mengandung sedikit selulosa (Vijayanagar, et.all, 2010). Dan secara KLT-Bioautografi dan difusi agar ekstrak dietil eter terstandar herba belimbing tanah (Oxalis corniculata L.) sangat potensial memberikan aktivitas terhadap beberapa mikroba patogen (Herwin, 2013).

Untuk mengetahui toksisitas suatu ekstrak maka dilakukan pengujian toksisitas dimaksudkan untuk memaparkan adanya efek toksik dan batas keamanan penggunaan suatu tanaman sebagai obat tradisional (Cassaret and Doull's, 1991). Suatu ekstrak dinyatakan bersifat toksik menurut metode Brine Shrimp Lethality Test jika memiliki Lethal Concentration ( $\left.\mathrm{LC}_{50}\right)$ kurang dari $1000 \mu \mathrm{g} / \mathrm{ml}$ (Meyer, 1982). Jika hasil uji Brine Shrimp Lethality Test menunjukkan bahwa ekstrak tumbuhan bersifat toksik maka dapat dikembangkan ke penelitian yang lebih lanjut berupa penelitian sitotoksik tumbuhan sebagai pengembangan obat antikanker (Rosenda, 2009).

Berdasarkan uraian tersebut, maka akan dilakukan penelitian toksisitas ekstrak dietil eter herba belimbing tanah (Oxalis corniculata L.) terhadap larva udang (Artemia salina
Leach) dengan metode Brine Shrimp Lethality Test sehingga dapat diketahui tingkat toksisitas dari herba belimbing tanah (Oxalis corniculata L.)

\section{METODE PENELITIAN}

\section{Tempat dan Waktu Penelitian}

Penelitian dilaksanakan di Farmakologi Fakultas Farmasi Universitas Muslim Indonesia Makassar. Pengujian toksisitas ekstrak dilakukan dengan metode Brine Shrimp Lethality Test (BSLT), dilaksanakan pada bulan Agustus Oktober 29013.

\section{Bahan dan Alat Penelitian}

Bahan dalam penelitian ini adalah air laut, aquadest, ekstrak dietil eter herba belimbing tanah (Oxalis corniculata L.), etanol $70 \%$, dietil eter, ragi, dan telur udang (Artemia salina Leach).

Alat yang digunakan dalam penelitian adalah aerator (Life $Q_{3}$ ), alat-alat gelas, lampu, mikropipet (Gilson), Rotavapor (IKA rv 10), seperangkat alat maserasi, timbangan kasar (Triple Beam), timbangan analitik (Ohaus) dan vial.

\section{Presedur Penelitian}

Belimbing tanah (Oxalis corniculata L.) yang diperoleh dari Mamuju Sulawesi Barat terlebih dahulu disortasi dengan tujuan untuk memisahkan kotoran-kotoran yang 
Toxicity Test Diethyl Ether Ekstract Oxalis corniculata L. Herb On Brine Shrimp Lethality Test Method

melekat pada sampel sehingga sampel yang dibutuhkan sesuai dengan yang diperlukan. Proses pemisahan kotoran dilakukan dengan air mengalir hingga bersih dan diangin-anginkan diudara bebas dan tidak terkena matahari secara langsung sehingga diperoleh simplisia dan diekstraksi.

\section{Ekstraksi Sampel}

Ekstraksi secara maserasi dengan pelarut etanol

Sampel beruwas laut (Scaevola taccada (Gaertn.) Roxb.) yang telah dikeringkan, ditimbang sebanyak 300 gram kemudian dimasukkan ke dalam wadah maserasi. Ditambahkan etanol $70 \%$ hingga simplisia tersebut terendam seluruhnya sebanyak 5 liter dan dibiarkan selama 5 hari dengan pegadukan beberapa kali. Ekstrak cair yang diperoleh diuapkan dengan menggunakan rotavapor hingga diperoleh ekstrak etanol kental.

\section{Ekstraksi dengan pelarut $\mathbf{n}$-heksan}

Ekstrak etanol yang diperoleh kemudian dipartisi padat-cair menggunakan pelarut n-heksan. Ekstrak etanol kental ditimbang sebanyak 30 gram disuspensikan sebanyak $30 \mathrm{ml}$ n-heksan dalam corong pisah, dikocok sampai merata dan didiamkan sampai terjadi pemisahan dari fase residu dan fase $n$ heksan, dipisahkan fase fase $n$-heksan kemudian fase residu dimasukkan kembali ke dalam corong pisah dan diekstraksi lagi dengan n-heksan dan dilakukan hingga jernih. Fraksi nheksan yang diperoleh dari beberapa kali penyaringan disatukan kemudian diuapkan hingga diperoleh fraksi kental.

\section{Ekstraksi dengan pelarut dietil eter}

Residu dari n-heksan yang diperoleh kemudian dipartisi padat-cair menggunakan pelarut dietil eter. Residu n-heksan disuspensikan dengan sebanyak $30 \mathrm{ml}$ dietil eter ke dalam corong pisah, dikocok sampai merata dan didiamkan sampai terjadi pemisahan dari fase residu dan fase dietil eter, dipisahkan fase residu dan fase dietil eter kemudian fase residu dimasukkan kembali ke dalam corong pisah dan diekstraksi lagi dengan dietil eter, dilakukan hingga jernih. Fraksi dietil eter yang diperoleh dari beberapa kali penyaringan disatukan kemudian diuapkan sampai mendapatkan fraksi kental.

\section{Penetasan telur larva Artemia salina} Leach (Meyer, 1982)

Sebanyak 50 gram telur Artemia salina Leach, direndam dalam wadah yang berisi $200 \mathrm{ml}$ air laut pada kondisi pH 7 dibawah cahaya lampu dan dilengkapi dengan aerator pada suhu $25^{\circ} \mathrm{C}$. Telur udang akan menetas 
Toxicity Test Diethyl Ether Ekstract Oxalis corniculata L. Herb On Brine Shrimp Lethality Test Method

setelah 24 jam dan menjadi larva. Larva yang berumur 2 hari (48 jam) yang akan digunakan sebagai hewan uji.

\section{Pengujian toksisitas ekstrak dietil} eter terstandar herba belimbing tanah (Oxalis corniculata L.)

Ekstrak dietil eter kental ditimbang sebanyak $100 \mathrm{mg}$ dilarutan dengan dietil eter $10 \mathrm{ml}$ sehingga diperoleh konsentrasi $100 \mathrm{mg} / 10 \mathrm{ml}$ sebagai larutan persediaan (stok). Dari sediaan tersebut dipipet $0.01,0.05$, $0.1,0.5,1,5,10,50$ dan $100 \mu \mathrm{l} / \mathrm{ml}$, selanjutnya dietil eter diuapkan. Untuk kontrol yaitu pelarut dietil eter $10 \mu \mathrm{l}$ dalam $10 \mathrm{ml}$ air laut, kemudian dipipet $0.01,0.05,0.1,0.5,1,5,10,50$, dan $100 \mu \mathrm{l} / \mathrm{ml}$ ke dalam masing-masing vial.
Ke dalam masing-masing vial yang berisi fraksi dietil eter dan kontrol dengan konsentrasi $0.01,0.05,0.1$, $0.5,1,5,10,50$ dan $100 \mu \mathrm{l} / \mathrm{ml}$ ditambahkan $5 \mathrm{ml}$ air laut, lalu dimasukkan 10 ekor larva udang Artemia salina Leach. Ke dalam tiap vial ditambahkan 1 tetes suspensi ekstrak ragi ( $3 \mathrm{mg}$ dalam $5 \mathrm{ml}$ air laut) sebagai sumber makanan. Dicukupkan volumenya sampai $10 \mathrm{ml}$. Vial-vial uji kemudian disimpan di tempat yang cukup mendapat sinar lampu. Setelah 24 jam dilakukan pengamatan terhadap jumlah larva yang mati. Untuk tiap sampel dan kontrol dilakukan pengulangan sebanyak 3 kali.

\section{HASIL PENELITIAN}

Tabel 1. Hasil Determinasi Herba Belimbing Tanah (Oxalis corniculata L.) Asal Mamuju Sulawesi Barat

\begin{tabular}{cccc}
\hline No. & $\begin{array}{c}\text { Nama Tumbuhan } \\
\text { Indonesia }\end{array}$ & $\begin{array}{c}\text { Nama Tumbuhan } \\
\text { Mamuju }\end{array}$ & Nama Species \\
\hline 1. & Calincing & Belimbing Tanah & Oxalis corniculata L. \\
\hline
\end{tabular}

Tabel 2. Hasil Ekstraksi Simplisia Herba Belimbing Tanah (Oxalis corniculata L.) Asal Mamuju Sulawesi Barat

\begin{tabular}{ccccc}
\hline $\begin{array}{c}\text { Berat Simplisia } \\
\text { (gram) }\end{array}$ & $\begin{array}{c}\text { Ekstrak Etanol } \\
\text { (gram) }\end{array}$ & $\begin{array}{c}\text { Ekstrak Etanol Yang } \\
\text { Dipartisi (gram) }\end{array}$ & $\begin{array}{c}\text { Ekstrak Dietil } \\
\text { Eter (gram) }\end{array}$ & $\begin{array}{c}\text { Residu } \\
\text { (gram) }\end{array}$ \\
\hline 700 & 75 & 50 & 38 & 8 \\
\hline
\end{tabular}


Toxicity Test Diethyl Ether Ekstract Oxalis corniculata L. Herb On Brine Shrimp Lethality Test Method

Tabel 3. Data Hasil Pengamatan Kematian Larva Udang Artemia salina Leach setelah 24 Jam Perlakuan

\begin{tabular}{cccc}
\hline No & Konsentrasi (\%) & $\begin{array}{c}\text { Jumlah Rata-Rata Yang } \\
\text { Mati }\end{array}$ & $\begin{array}{c}\text { Jumlah Rata-Rata Yang } \\
\text { Hidup }\end{array}$ \\
\hline 1. & 0.01 & 0 & 10 \\
2. & 0.05 & 2 & 8 \\
3. & 0.1 & 3 & 7 \\
4. & 0.5 & 3 & 7 \\
3. & 1 & 4 & 6 \\
4. & 5 & 5 & 5 \\
5. & 10 & 6 & 4 \\
6. & 50 & 7 & 3 \\
7. & 100 & 8 & 2 \\
\hline
\end{tabular}

PEMBAHASAN

1. Determinasi

Tumbuhan

Belimbing

Tanah

(Oxalis

corniculata L.) Asal Mamuju

Sulawesi Barat

Berdasarkan

hasil

determinasi tumbuhan belimbing tanah (Oxalis corniculata L.) dari laboratorium FarmakognoniFitokimia Fakultas Farmasi Universitas Muslim Indonesia dan LIPI Indonesia diperoleh bahwa sampel yang digunakan bernama Calincing/Belimbing tanah dengan species Oxalis corniculata L., terlihat pada tabel 1 .

\section{Ekstraksi Herba Belimbing Tanah} (Oxalis corniculata L.)

Simplisia kering sebanyak 700 gram diekstraksi dengan metode maserasi menggunakan etanol 96\% diperoleh 75 gram ekstrak etanol kering. Dengan 50 gram ekstrak etanol kering dipartisi dengan metode padat cair diperoleh 38 gram ekstrak dietil eter dan 8 gram residu, terlihat pada tabel 2 .

3. Pengujian toksisitas ekstrak dietil eter belimbing tanah (Oxalis corniculata L.) terhadap kelinci janta (Oryctolagus cuniculus) dengan metode Brine Shrimp Lethality Test (BST)

Ekstrak dietil eter terstandar herba belimbing tanah (Oxalis corniculata L.) dengan konsentrasi $0.01,0.05,0.1,0.5,1,5,10,50,100$ $\mu \mathrm{g} / \mathrm{ml}$ dan dietil eter sebagai pembanding dengan konsentrasi yang sama diujikan terhadap larva udang Artemia salina Leach dengan parameter kematian setelah 24 jam perlakuan sebagai respon toksisitas, jumlah kematian larva udang pada tiap-tiap konsentrasi dapat dilihat pada tabel 3 .
4. Grafik
Hubungan
Log
Konsentrasi Ekstrak Dietil Eter 
Toxicity Test Diethyl Ether Ekstract Oxalis corniculata L. Herb On Brine Shrimp Lethality Test Method

$\begin{array}{ll}\text { Terstandar Herba Belimbing } & \text { L.) adalah } 4,17 \pm 2,59 \mu \mathrm{g} / \mathrm{ml} \text {. Hasil } \\ \text { Tanah (Oxalis corniculata L.) } & \text { ini menunjukkan bahwa ekstrak } \\ \text { Terhadap Harga Probit Sesuai } & \text { dietil eter terstandar herba } \\ \text { Persentase Kematian } & \text { Belimbing Tanah (Oxalis corniculata } \\ \text { Hasil dari analisis probit } & \text { L.) bersifat toksik dan memiliki } \\ \text { menunjukkan nilai LC } 50 \text { dari ekstrak } & \text { potensi sebagai antikanker dengan } \\ \text { dietil eter terstandar herba } & \text { nilai } \mathrm{R}^{2}=0.984 \text {, terlihat pada grafik } \\ \text { Belimbing Tanah (Oxalis corniculata } & \text { dibawah: }\end{array}$

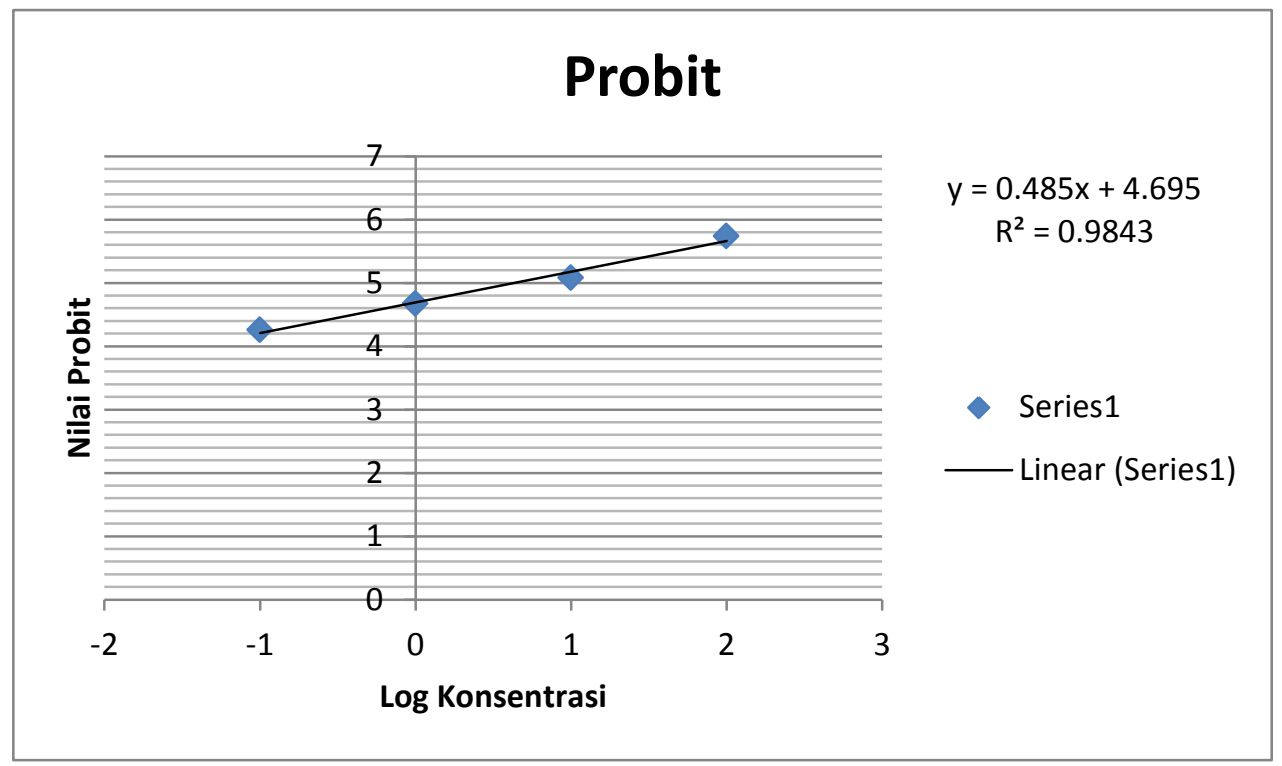

\section{KESIMPULAN}

Hasil penelitian dan hasil analisis probit disimpulkan bahwa ekstrak dietil eter terstandar herba belimbing tanah (Oxalis corniculata L.) bersifat toksik dan memiliki potensi sebagai antikanker dengan nilai $\mathrm{LC}_{50}$ $4,17 \pm 2,59 \mu \mathrm{g} / \mathrm{ml}$.

\section{DAFTAR PUSTAKA}

Anonim. 2011. Plantamor Situs dunia tumbuhan, (Online), (http://www.plantamor.com/in dex.php? Plant=928, Diakses 2 Agustus 2013).
Alam, G. 2002. BST Sebagai Bioassay Dalam Isolasi Senyawa Bioaktif dari Bahan Alam. Majalah Farmasi dan Farmakologi, vol 6.

Casarett, L.J., and Doul J., 1991. Toxicology, The Basic Sceine of Poison, First Edition, Mac Millan Publishing, Co, Inc, New York.

Ditjen POM., 1986. Sediaan Galenik. Jakarta : Departemen Kesehatan RI. 10-15

LIPI, 2011. Hasil Identifikasi / Determinasi Tumbuhan. (Laporan 
Toxicity Test Diethyl Ether Ekstract Oxalis corniculata L. Herb On Brine Shrimp Lethality Test Method

No.1178/IPH.1.02/if.8/VIII/20

11). Lembaga IImu Penelitian Indonesia : Cibinong.

Loomis, T.A., 1978, Toksikologi Dasar, edisi III, penerjemah Imono Argo, IKIP Semarang Press.

McLaughlin, J.E., 1991. A Blind Comparison of Simple Benzch Top Bioassay and Human Tumor Cell Cytotoxicities as Antitumor Prescreens, Natural Product Chemistry.

Elsivier, Amsterdam.

Meyer, B.N., Ferrigni, N. R., Putman, J. E., Jacbsen, L. B., Nicols, D.E., and McLaughlin, J. L. 1982. Brine Shrimp : A Comvenient General Bioassay For Active Plant Constituent. Plant Medica.

Mudjiman, A. 1989. Udang Renik Air Asin. Brata Karya Aksara, Jakarta.

Mukono, H.J. 2005. Toksikologi Lingkungan. Airlangga University Press, Surabaya.
Priyanto. 2009. Toksikologi. Mekanisme, Terapi Antidotum dan Penilaian Resiko. Lembaga Studi dan Konsultasi Farmakologi (Leskonfi), Depok.

Ramadhani, Ahmad Nur. 2009. Uji Toksisitas Akut Ekstrak Etanol Daun Sukun (Artocarpus altilis) Terhadap Larva Artemia Salina Leach Dengan Metode Brine Shrimp Lethality Test (BST). Fakultas Kedokteran. Universitas Diponegoro, Semarang.

Rosenda, E.H. Anandita dan Suhardjono. 2009. Uji Toksisitas Ekstrak Etanol Daun Kemangi (Ocimun sanctum Linn.) Terhadap Larva Artemia salina Leach Dengan Metode Brine Shrimp Lethality Test. Majalah Farmasi Indonesia, Semarang.

Soemirat, Juli dkk. 2009. Toksikologi Lingkungan. Gadjah Mada Uiversity Press, Yogyakarta.

Steenis, Van.C.G.G.J. dkk. 2008. Flora. PT. Pradnya Paramita: Jakarta . 